\title{
Surgical mitral valve replacement using direct implantation of Sapien 3 valve in a patients with severe mitral annular calcification without adjunctive techniques, a case report
}

\author{
Turki B. Albacker ${ }^{*}$ (D, Bakir Bakir, Ahmed Eldemerdash, Fayez Elshaer, Hanan Albacker, Murtadha Alawami and
} Tariq Kashour

\begin{abstract}
Background: Mitral annular calcification (MAC) occurs represents a challenge to surgeons during mitral valve (MV) surgery with increased perioperative risk.

Case presentation: We describe a challenging case of an elderly female patient with multiple comorbidities who presented with symptoms and signs of heart failure with a previous history of mechanical aortic valve replacement 15 years prior to presentation. Echocardiogram showed severe mitral stenosis and regurgitation with severe calcification of the mitral annulus. Given her high-risk profile and unavailability of suitable percutaneous therapeutic options we decided to replace her mitral valve with Sapien 3 valve under direct exposure. The case describes the technical details for the valve implantation and demonstrates the viability of this option in high risk surgical patients without the need for adjunct techniques like predilatation, additional supporting sutures or patches with a review of the literature on open surgical implantation of Sapien 3 valve.
\end{abstract}

Conclusion: Direct open surgical implantation of Sapien 3 valve can be implanted safely in patients with severe MAC, without predilatation and without the use of other adjunctive techniques like fixation sutures or patches.

Keywords: Mitral valve replacement, Sapien 3 valve, MAC, Direct implantation

\section{Background}

Mitral annular calcification (MAC) occurs in $10 \%$ of the population with increasing prevalence with advancing age (up to $40 \%$ above 80 years) [1,2] and it is independently associated with all-cause mortality [3]. It represents a challenge to surgeons during mitral valve (MV) surgery with up to 6 folds increase in perioperative risk [4]. Unfortunately, percutaneous interventions in this high-risk group of patients still carry a higher risk than open surgery with 30 -day mortality of $25 \%$ and 1 -year mortality of $53.7 \%[5,6]$.

* Correspondence: talbacker@ksu.edu.sa

Cardiac Sciences Department, King Fahad Cardiac Center, College of Medicine, King Saud University, Riyadh, Saudi Arabia
We report in this paper a case of open surgery for mitral valve replacement (MVR) in a high-risk patient with severe MAC using the direct implantation of Sapien 3 valve that is designed for percutaneous use without the use of any adjunctive techniques and we reviewed the literature in this subject. This is the first case implanted directly without the use of fixation sutures or any other adjunctive techniques.

\section{Case presentation}

This is a case of a 75-year-old lady who is known to have diabetes mellitus, hypertension, hypothyroidism, adrenal suppression, previous history of stroke and a history of aortic valve replacement with mechanical prosthesis 15 years prior to presentation. She was admitted urgently to

(c) The Author(s). 2020 Open Access This article is distributed under the terms of the Creative Commons Attribution 4.0 International License (http://creativecommons.org/licenses/by/4.0/), which permits unrestricted use, distribution, and 
the cardiac care unit with shortness of breath on exertion class III and lower limb edema. Chest X-Ray was compatible with pulmonary edema. Echocardiogram showed a well-functioning aortic prosthesis but severe mitral valve stenosis (MS) and mitral regurgitation (MR) with severe Mitral annular calcification (MAC) (video 1, 2).

The patient was stabilized medically then underwent Cardiac CT to characterize the MAC that appeared as a dense horseshoe calcification occupying most of the circumference of the mitral annulus (Video 3, 4). The case was discussed in the multidisciplinary rounds and she was deemed very high risk for surgical intervention with a calculated STS risk score of (19.5\%). Given the patient age and frailty, it was not reasonable to decalcify the mitral annulus and reconstruct the annulus that may lead to high risk of Atrio-ventricular (AV) groove dissociation. So the decision was taken to implant the Sapien 3 valve in the mitral position under direct vision after redo sternotomy. To predict the risk of post procedure LVOT obstruction, the neo LVOT was assessed preoperatively during systole by measuring the distance from the inter- ventricular septum to the frame of the simulated transcatheter valve and then calculating the neo LVOT area which was $211 \mathrm{~mm}^{2}$ in this case. However, there is no set threshold for LVOT obstruction when this procedure is done using transatrial approach and the anterior mitral leaflet is excised since the calculated neo LVOT is underestimated due to the fact that there is flow through the cells of the valve stent frame.

Intraoperatively, and after exposing the mitral valve, the anterior leaflet was excised and was thickened and fibrosed (Video 5). The posterior calcium bar was so prominent that made the MV orifice very small not even accommodating size 25 regular MV prosthesis sizer. We decided preoperatively to use the largest Sapien 3 valve (size 29) based on the mitral orifice size from CT scan with additional $20 \%$ oversizing. We loaded the valve on the balloon in a similar way to the transapical aortic approach and we advanced the balloon inside the ventricle until the end of the valve stents was just across the mitral annulus (Video 6). We elected not to perform a balloon predilatation to avoid fracture of the calcium body or to induce atrioventricular groove rupture. Subsequently one operator was responsible for inflating the balloon and another one was responsible for stabilizing the position of the valve across the annulus with fine tuning the direction of the valve during inflation of the balloon. The balloon was inflated until an atmospheric pressure of 4 and kept inflated for $15 \mathrm{~s}$ then deflated (Video 7). The valve was nicely deployed and stable in position with normal movement of the leaflets. We did not use supportive sutures to fix the valve nor utilized any patches or skirts around the valve. The patient was weaned smoothly from bypass and intraoperative transesophageal echo was performed and showed that the valve is well seated in position with no evidence of any paravalvular leak (Video 8, 9). The mean gradient across the valve was $4 \mathrm{mmHg}$.

\section{Discussion}

Surgery for MVR carries very high risk in patients with MAC and percutaneous MVR techniques did not result in lower risk in this group of patients given its limitations in implantation techniques and the risks of paravalvular leaks and Left ventricular outflow tract (LVOT) obstruction. Hence there is a great need for further development in this field.

The first world-wide case of open antegrade placement of transcatheter valve for MVR was reported by Thierry Carrel et al. in June, 2012. They used SAPIEN XT size 26 valve in an 81 years old woman with severe MR \& moderate MS. They decided to use this innovative method to avoid debridement of severe MAC and also due to small annulus, only $19 \mathrm{~mm}$ sizer were able to pass after resection of the anterior and part of the posterior leaflet [7]. Since that time only 36 cases were reported in the literature using open antegrade placement of transcatheter valve for MVR (Table 1). All these cases were performed using additional adjunctive techniques for implantation including balloon pre-dilatation, suture fixation, Teflon skirts around the valve and patches around the valve and sutured to the left atrial wall.

The direct surgical implantation of the percutaneous valves has some potential benefits including better orientation of the valve with accurate control of the device depth that may results in lower risk of paravalvular leak. It also allows for excision of the native leaflets that eliminates the risk of LVOT obstruction and decreases the risk of embolization.

In our case, we elected not use balloon pre-dilatation of the annulus in order to avoid the risk of calcium disruption or annular tear. We also wanted to avoid oversizing of the MV orifice before the valve deployment that may lead to paravalvular leak. We also decided not to place any additional fixation sutures for the device neither to use any patch around the device in order to shorten the cross-clamp time as much as possible especially in our elderly lady. We used $20 \%$ valve oversizing as the only technique to fix the valve in place using the device radial force. This is the first report of direct catheter based mitral valves implantation without adjunctive techniques.

The SITRAL study (Surgical Implantation of TRAnscatheter valve in Native Mitral Annular Calcification Study) [21] was designed to establish the safety and feasibility of the SAPIEN 3 valve for severe MS/MR associated with severe calcification in high risk or inoperable 
Table 1 Literature Summary of Open Antegrade Placement of Transcatheter Valve for Mitral Valve Replacement

\begin{tabular}{|c|c|c|c|c|c|c|c|c|c|c|c|}
\hline & Author & year & $\begin{array}{l}\text { No. of } \\
\text { cases }\end{array}$ & $\begin{array}{l}\text { Age/ } \\
\text { Sex }\end{array}$ & $\begin{array}{l}\text { Type of } \\
\text { valve }\end{array}$ & $\begin{array}{l}\text { Valve } \\
\text { size }\end{array}$ & Redo & Access & MAC & indication & Note \\
\hline 1 & $\begin{array}{l}\text { Carrel et al. } \\
{[7]}\end{array}$ & 2012 & 1 & $81 / F$ & Sapien XT & 26 & yes & Sternotomy & yes & $\begin{array}{l}\text { Severe } \\
\text { MR/ } \\
\text { Moderate } \\
\text { MS }\end{array}$ & 1st case \\
\hline 2 & $\begin{array}{l}\text { Astarci et al. } \\
{[8]}\end{array}$ & 2013 & 1 & $62 / F$ & Sapien XT & 26 & No & Sternotomy & yes & $\begin{array}{l}\text { Severe MS/ } \\
\text { Moderate } \\
\text { MR }\end{array}$ & $\begin{array}{l}\text { AVR }+ \text { MVR+ } \\
\text { CABG }\end{array}$ \\
\hline 3 & $\begin{array}{l}\text { Ferrari et al. } \\
\text { [9] }\end{array}$ & 2014 & 1 & $60 / M$ & Sapien XT & 29 & No & $\begin{array}{l}\text { Rt } \\
\text { Thoracotomy }\end{array}$ & Yes & Severe MS & $\begin{array}{l}\text { Hx of chest radiation } \\
\text { Hx of TAVI }\end{array}$ \\
\hline 4 & Lee et. Al [10] & 2016 & 1 & $83 / F$ & Sapien XT & 29 & No & Sternotomy & Yes & Severe MR & \\
\hline 5 & $\begin{array}{l}\text { Murashita et. } \\
\text { Al [11] }\end{array}$ & 2016 & 1 & $71 / F$ & Sapien XT & 29 & No & Sternotomy & Yes & Severe MS & \\
\hline 6 & $\begin{array}{l}\text { Baumgarten } \\
\text { et al. [12] }\end{array}$ & 2016 & 3 & $\begin{array}{l}\text { 1. } 89 / F \\
\text { 2. } 83 / F \\
\text { 3. } 85 / F\end{array}$ & $\begin{array}{l}\text { 1. Sapien XT } \\
\text { 2. Sapien XT } \\
\text { 3. Sapien } 3\end{array}$ & $\begin{array}{l}\text { 1. } 26 \\
\text { 2. } 26 \\
\text { 3. } 29\end{array}$ & $\begin{array}{l}1 . \\
\text { Yes } \\
2 . \\
\text { No } \\
3 . \\
\text { No }\end{array}$ & $\begin{array}{l}\text { Mini } \\
\text { Thoracotomy }\end{array}$ & $\begin{array}{l}1 . \\
\text { Yes } \\
2 . \\
\text { Yes } \\
3 . \\
\text { Yes }\end{array}$ & $\begin{array}{l}\text { 1. Severe } \\
\text { MS } \\
\text { 2. Severe } \\
\text { MS } \\
\text { 3. Severe } \\
\text { MS }\end{array}$ & Patient 3 had mild post op PVL \\
\hline 7 & $\begin{array}{l}\text { Langhammer } \\
\text { et al. [13] }\end{array}$ & 2017 & 4 & $\begin{array}{l}\text { 1. } 80 / \mathrm{F} \\
\text { 2. } 60 / \mathrm{M} \\
\text { 3. } 79 / \mathrm{F} \\
\text { 4. } 74 / \mathrm{F}\end{array}$ & $\begin{array}{l}\text { 1. Sapien } X T \\
\text { 2. Sapien } X T \\
\text { 3. Sapien XT } \\
\text { 4. Sapien } 3\end{array}$ & $\begin{array}{l}\text { 1. } 26 \\
\text { 2. } 29 \\
\text { 3. } 29 \\
\text { 4. } 29\end{array}$ & $\begin{array}{l}1 . \\
\text { No } \\
2 . \\
\text { Yes } \\
3 . \\
\text { No } \\
4 . \\
\text { No }\end{array}$ & Sternotomy & $\begin{array}{l}1 . \\
\text { Yes } \\
2 . \\
\text { Yes } \\
3 . \\
\text { Yes } \\
4 . \\
\text { Yes }\end{array}$ & $\begin{array}{l}\text { 1. Severe } \\
\text { MR/ } \\
\text { Moderate } \\
\text { MS } \\
\text { 2. Severe } \\
\text { MS } \\
\text { 3. Severe } \\
\text { MR/ } \\
\text { Moderate } \\
\text { MS } \\
\text { 4. Severe } \\
\text { MR/ } \\
\text { Moderate } \\
\text { MS }\end{array}$ & $\begin{array}{l}\text { 1. Concomitant Maze, mild PVL } \\
\text { 2. - } \\
\text { 3. Concomitant CABG/myomectomy } \\
\text { 4. Post op mild transvalvular leak }\end{array}$ \\
\hline 8 & $\begin{array}{l}\text { Alfonsi et. } \\
\text { al [14]. }\end{array}$ & 2017 & 1 & $76 / F$ & Sapien XT & 26 & No & Sternotomy & Yes & Severe MS & 5. Post op mild PVL \\
\hline 9 & $\begin{array}{l}\text { Koehle et al. } \\
{[15]}\end{array}$ & 2017 & 1 & $66 / F$ & Sapien XT & 26 & yes & Sternotomy & No & Severe MS & $\begin{array}{l}\text { Inserted inside a mechanical } \\
\text { prosthesis ring }\end{array}$ \\
\hline 10 & $\begin{array}{l}\text { Polomsky } \\
\text { et al. [16] }\end{array}$ & 2017 & 2 & $\begin{array}{l}\text { 1. } 81 / \mathrm{M} \\
\text { 2. } 69 / \mathrm{F}\end{array}$ & Sapien 3 & $\begin{array}{l}\text { 1. } 26 \\
\text { 2. } 26\end{array}$ & No & Sternotomy & Yes & $\begin{array}{l}\text { 1. Mixed } \\
\text { 2. Severe } \\
\text { MS }\end{array}$ & \\
\hline 11 & $\begin{array}{l}\text { Gallo et al. } \\
\text { [17] }\end{array}$ & 2018 & 1 & $73 / F$ & Sapien 3 & 29 & No & Sternotomy & Yes & Severe MS & \\
\hline 12 & $\begin{array}{l}\text { Russell et al. } \\
\text { [18] }\end{array}$ & 2018 & 8 & $\begin{array}{l}\text { 1. } 65 / \mathrm{M} \\
\text { 2. } 78 / \mathrm{F} \\
\text { 3. } 74 / \mathrm{M} \\
\text { 4. } 87 / \mathrm{F} \\
5.80 / \mathrm{M} \\
6.77 / \mathrm{M} \\
7.75 / \mathrm{F} \\
8.69 / \mathrm{F}\end{array}$ & $\begin{array}{l}\text { Sapien } 3 \\
\text { (all) }\end{array}$ & $\begin{array}{l}1.29 \\
2.29 \\
3.29 \\
4.29 \\
\text { 5. } 29 \\
6.29 \\
7.26 \\
8.26\end{array}$ & $\begin{array}{l}1 . \\
\text { Yes } \\
2 . \\
\text { Yes } \\
3 . \\
\text { Yes } \\
4 . \\
\text { No } \\
5 . \\
\text { Yes } \\
6 . \\
\text { Yes } \\
7 . \\
\text { No } \\
8 . \\
\text { No }\end{array}$ & $\begin{array}{l}\text { Sternotomy/ } \\
\text { Thoracotomy }\end{array}$ & $\begin{array}{l}\text { Yes } \\
\text { (all) }\end{array}$ & NA & $\begin{array}{l}\text { PVL immediately post-implantation } \\
\text { was none or trace in } 6 \text { patients and } \\
\text { mild in } 1 . \text { There were no cases of } \\
\text { moderate or severe PVL. One patient } \\
\text { with mild PVL post-TMVR developed } \\
\text { hemolysis } 6 \text { months post-TMVR that } \\
\text { was successfully treated with } \\
\text { percutaneous closure using a vascular } \\
\text { plug. There were no procedural major } \\
\text { complications, including clinically } \\
\text { significant LVOT obstruction, annular } \\
\text { rupture, valve embolization, or migration. } \\
\text { The mean length of stay has been } 7.9 \\
\text { days following surgery. There were no } \\
\text { in-hospital or } 30 \text {-day mortalities. No } \\
\text { patient had a stroke. One patient (\#5) } \\
\text { died at home } 7 \text { months post-operatively; } \\
\text { all other patients are alive. }\end{array}$ \\
\hline
\end{tabular}


Table 1 Literature Summary of Open Antegrade Placement of Transcatheter Valve for Mitral Valve Replacement (Continued)

\begin{tabular}{|c|c|c|c|c|c|c|c|c|c|c|c|}
\hline & Author & year & $\begin{array}{l}\text { No. of } \\
\text { cases }\end{array}$ & $\begin{array}{l}\text { Age/ } \\
\text { Sex }\end{array}$ & $\begin{array}{l}\text { Type of } \\
\text { valve }\end{array}$ & $\begin{array}{l}\text { Valve } \\
\text { size }\end{array}$ & Redo & Access & MAC & indication & Note \\
\hline 13 & $\begin{array}{l}\text { Tabachnick } \\
\text { et al. [19] }\end{array}$ & 2018 & 10 & $\begin{array}{l}\text { 1. 87/F } \\
\text { 2. 84/F } \\
\text { 3. 86/F } \\
\text { 4. 87/F } \\
\text { 5. } 77 / \mathrm{F} \\
\text { 6. 71/F } \\
\text { 7. } 76 / \mathrm{F} \\
\text { 8. 70/F } \\
\text { 9. 83/F } \\
\text { 10. 80/F } \\
\text { ? details } \\
\text { 80/F }\end{array}$ & $\begin{array}{l}\text { 1. Sapien XT } \\
\text { 2. Sapien } 3 \\
\text { 3. Sapien } 3 \\
\text { 4. Sapien } 3 \\
\text { 5. Sapien } 3 \\
\text { 6. Sapien XT } \\
\text { 7. Sapien XT } \\
\text { 8. Sapien XT } \\
\text { 9. Sapien } 3 \\
\text { 10. Sapien } \\
\text { XT }\end{array}$ & $\begin{array}{l}1.26 \\
2.26 \\
3.29 \\
4.29 \\
5.26 \\
6.26 \\
7.26 \\
8.26 \\
9.29 \\
10 . \\
29\end{array}$ & NA & $\begin{array}{l}\text { Mini } \\
\text { Thoracotomy/ } \\
\text { Robotic }\end{array}$ & Yes & $\begin{array}{l}\text { 1. Stenosis } \\
\text { 2. Mixed } \\
\text { 3. Mixed } \\
\text { 4. Mixed } \\
\text { 5. Stenosis } \\
\text { 6. Stenosis } \\
\text { 7. Mixed } \\
\text { 8. Stenosis } \\
\text { 9. Mixed } \\
\text { 10. Mixed }\end{array}$ & \\
\hline 14 & $\begin{array}{l}\text { Ahmad et al. } \\
{[20]}\end{array}$ & 2019 & 1 & $68 / F$ & Sapien XT & 26 & No & Sternotomy & Yes & Severe MS & \\
\hline
\end{tabular}

patients. It was started on September, 2016 and is estimated to be completed on December, 2019.

\section{Conclusion}

Direct open surgical implantation of Sapien 3 valve can be implanted safely in patients with severe MAC, who are at high risk of complications from decalcification of the mitral annulus, without predilatation and without the use of other adjunctive techniques like fixation sutures or patches. Longer follow up for these valves are needed to show the long-term outcomes of these techniques.

\section{Supplementary information}

Supplementary information accompanies this paper at https://doi.org/10. 1186/s13019-020-1083-8.

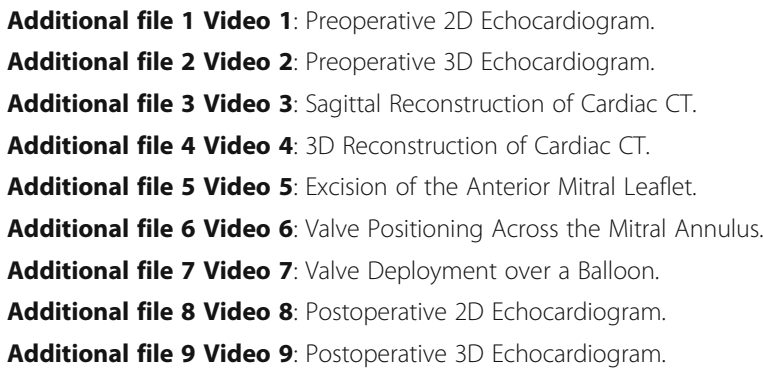

\section{Abbreviations}

AV: Atrio-Ventricular; LVOT: Left Ventricular Outflow Tract; MAC: Mitral Annular Calcification; MR: Mitral Regurgitation; MS: Mitral Stenosis; MV: Mitral Valve; MVR: Mitral Valve Replacement

\section{Acknowledgements}

Non-Applicable.

\section{Authors' contributions}

All authors have made substantial contributions to the conception of the work; interpretation of data; and have drafted the work. All authors have approved the submitted version and agreed both to be personally accountable for the author's own contributions and to ensure that questions related to the accuracy or integrity of any part of the work, even ones in which the author was not personally involved, are appropriately investigated, resolved, and the resolution documented in the literature.
Funding

There is no funding for this study.

Availability of data and materials

- Data sharing is not applicable to this article as no datasets were generated or analysed during the current study.

Ethics approval and consent to participate

Non-Applicable.

Consent for publication

Non-Applicable.

\section{Competing interests}

There has been no duplicate publication or submission of this manuscript elsewhere. All authors have read and approved the manuscript. There is no ethical problem or conflict of interest to be declared for any of the coauthors.

Received: 13 December 2019 Accepted: 17 February 2020

Published online: 24 February 2020

References

1. Fox E, Harkins D, Taylor H, McMullan M, Han H, Samdarshi T, et al. Epidemiology of mitral annular calcification and its predictive value for coronary events in African Americans: the Jackson cohort of the atherosclerotic risk in communities study. Am Heart J. 2004;148:979-84.

2. Savage DD, Garrison RJ, Castelli WP, McNamara PM, Anderson SJ, Kannel WB, et al. Prevalence of submitral (anular) calcium and its correlates in a general population-based sample (the Framingham study). Am J Cardiol. 1983:51:1375-8.

3. Ramaraj R, Manrique C, Hashemzadeh M, Movahed M. Mitral annulus calcification is independently associated with all-cause mortality. Exp Clin Cardiol. 2013;18(1):e5-7.

4. Feindel CM, Tufail Z, David TE, Ivanov J, Armstrong S. Mitral valve surgery in patients with extensive calcification of the mitral annulus. J Thorac Cardiovasc Surg. 2003;126:777-82.

5. Guerrero M, Dvir D, Himbert D, et al. Transcatheter mitral valve replacement in native mitral valve disease with severe mitral annular calcification: results from the first multicenter global registry. J Am Coll Cardiol Intv. 2016;9: 1361-71.

6. Guerrero M, Urena M, Himbert D, et al. 1-year outcomes of transcatheter mitral valve replacement in patients with severe mitral annular calcification. J Am Coll Cardiol. 2018;71:1841-53.

7. Carrel T, Wenaweser P, Reineke S, Simon R, Eberle B, Windecker S, Huber C. Worldwide first surgical implantation of a transcatheter valved stent in mitral position. Cardiovasc Med. 2012;15(6):202-5.

8. Astarci P, Glineur D, De Kerchove L, El Khoury G. Transcatheter valve used in a bailout technique during complicated open mitral valve surgery. Interact Cardiovasc Thorac Surg. 2013;17(4):745-7. 
9. Ferrari E, Niclauss L, Locca D, Marcucci C. On-pump fibrillating heart mitral valve replacement with the SAPIEN ${ }^{T M} X T$ transcatheter heart valve. Eur J Cardiothorac Surg. 2014;45(4):749-51.

10. Lee R, Borchelt B, George I. Hybrid Surgical Mitral Valve Replacement With a Transcatheter Valve in the Setting of Mitral Annular Calcification; 2018.

11. Murashita T, Suri RM, Daly RC. Sapien XT transcatheter mitral valve replacement under direct vision in the setting of significant mitral annular calcification. Ann Thorac Surg. 2016;101:1171-4.

12. Baumgarten H, Squiers JJ, Brinkman WT, DiMaio JM, Gopal A, Mack MJ, Smith RL. Implantation of transcatheter aortic prosthesis in 3 patients with mitral annular calcification. Ann Thorac Surg. 2016;102:e433-5.

13. Langhammer B, Huber C, Windecker S, Carrel T. Surgical antegrade transcatheter mitral valve implantation for symptomatic mitral valve disease and heavily calcified annulus. Eur J Cardiothorac Surg. 2017;51(2):382-4.

14. Alfonsi J, Murana G, Corsini A, Savini C, Di Bartolomeo R, Pacini D. Transcatheter mitral valve implantation in open heart surgery: an off-label technique. Korean J Thorac Cardiovasc Surg. 2017;50(6):467-70.

15. Koehle M, Strote JA, Guadagnoli M, Oldemeyer JB. A novel mechanical mitral valve replacement using Sapien XT. Catheter Cardiovasc Interv. 2018; 92(5):983-7.

16. Polomsky M, Koulogiannis KP, Kipperman RM, Cohen BM, Magovern CJ, Slater JP, Xydas S, Marcoff L, Brown JM. Mitral valve replacement with Sapien 3 transcatheter valve in severe mitral annular calcification. Ann Thorac Surg. 2017;103:e57-9.

17. Gallo M, Demertzis S, Tiziano T and Ferrari E. Direct surgical transcatheter heart valve implantation in a calcified mitral valve. Published by MMCTS on behalf of the European Association for Cardio-Thoracic Surgery. 2018.

18. Russell HM, Guerrero ME, Salinger MH, Manzuk MA, Pursnani AK, Wang D, Nemeh H, Sakhuja R, Melnitchouk S, Pershad A, Fang HK, Said SM, Kauten J, Tang GH, Aldea G, Feldman TE, Bapat VN, George IM. Open atrial transcatheter mitral valve replacement in patients with mitral annular calcification. JACC. 2018;72(13):1437-48.

19. Tabachnick D. Percutaneous Valve in Native with and Without Mitral Valve Calcification: When To Go Hybrid. Presented in the Symposium on Interventional Echocardiography and Decision- making in Structural Heart Disease. 2nd annual meeting. Atlanta; 2018. https://www.asecho.org/wpcontent/uploads/2018/03/0905-Taberchnick-Percutaneous-Mitral-ValveWhen-to-go-Hybrid.pdf.

20. Ahmad T, Ludhani PM, Gurvitch R, Goldblatt J, Tatoulis J. Open surgical mitral valve replacement with a transcatheter Edwards Sapien-XT valve. ANZ J Surg. 2019;89(4):436-8.

21. Guerrero M. MITRAL (Mitral implantation of TRAnscatheter vaLves), 30-day outcomes of transcatheter MV replacement with severe mitral valve disease secondary to mitral annular calcification or failed annuloplasty rings. Presented at TCT, Denver, CO: November 1, 2017. (https://clinicaltrials.gov/ ct2/show/NCT02830204).

\section{Publisher's Note}

Springer Nature remains neutral with regard to jurisdictional claims in published maps and institutional affiliations.

Ready to submit your research? Choose BMC and benefit from:

- fast, convenient online submission

- thorough peer review by experienced researchers in your field

- rapid publication on acceptance

- support for research data, including large and complex data types

- gold Open Access which fosters wider collaboration and increased citations

- maximum visibility for your research: over $100 \mathrm{M}$ website views per year

At BMC, research is always in progress.

Learn more biomedcentral.com/submissions 